\title{
Q-METHOD BASED ENVIRONMENTAL AWARENESS MEASUREMENT IN TRANSPORTATION
}

\author{
Emma Logo \\ ${ }^{1}$ BME Faculty of Economic and Social Sciences, Department of Ergonomics and Psychology, Budapest, \\ Hungary
}

Received 30 December 2011; accepted 2 November 2012

\begin{abstract}
All human activities, including transportation have an impact and put pressure on the environment. If anybody would be asked with questionnaire or interview, claims to be environmentally conscious in transportation, but acts another way. Environmental awareness in transport is difficult to measure with "traditional" way, because the real actions and the human subjectivity cannot be measured these ways. The idea behind the development of Q-methodology was to inquire into the subjectivity of human mind. This article theoretically investigated the possibility of measuring environmental awareness in road transportation with this methodology.
\end{abstract}

Keywords: Q-method, decision making, environmental awareness.

\section{Introduction}

The social sciences are always dealing with subjectivity, whether it is seen as a black box or put explicitly into the foreground of scientific inquiry. However, although it is clear that every human action is motivated by subjective perceptions and interpretations, the question of how and why exactly people see their world as they do confronts the social sciences with serious problems. In this article, authors have theoretically investigated the possibility of measuring environmental awareness in road transportation. Should be subjectivity seen as rooted so deeply within each individual that it is impossible to make any form of generalization or as influenced, or even determined, by external forces to such a degree that we can ignore the individual person and instead focus on social variables (e.g. gender, age or social status) or disembodied discourses? Both approaches have serious methodological shortcomings; either it is restricted to exploring subjectivity only on the level of profound but isolated case studies or have to neglect the concept of the 'subject' and understand it as a shallow reflection of external structures and forces. Q-methodology is a relative little-known form of research methodology within social science, even though it has been established for over 80 years (Barry and Proops, 1999). It is a qualitative but statistical approach, which provides study of subjectivity, a person's viewpoint, opinion, attitude (Fig. 1). Q-methodology is primarily an exploratory technique, it cannot prove hypotheses. However, it brings a sense of coherence to research questions that have many, potentially complex and social contested answers (Watts and Stenner, 2005).

\footnotetext{
${ }^{1}$ Corresponding author: emma@erg.bme.hu
} 


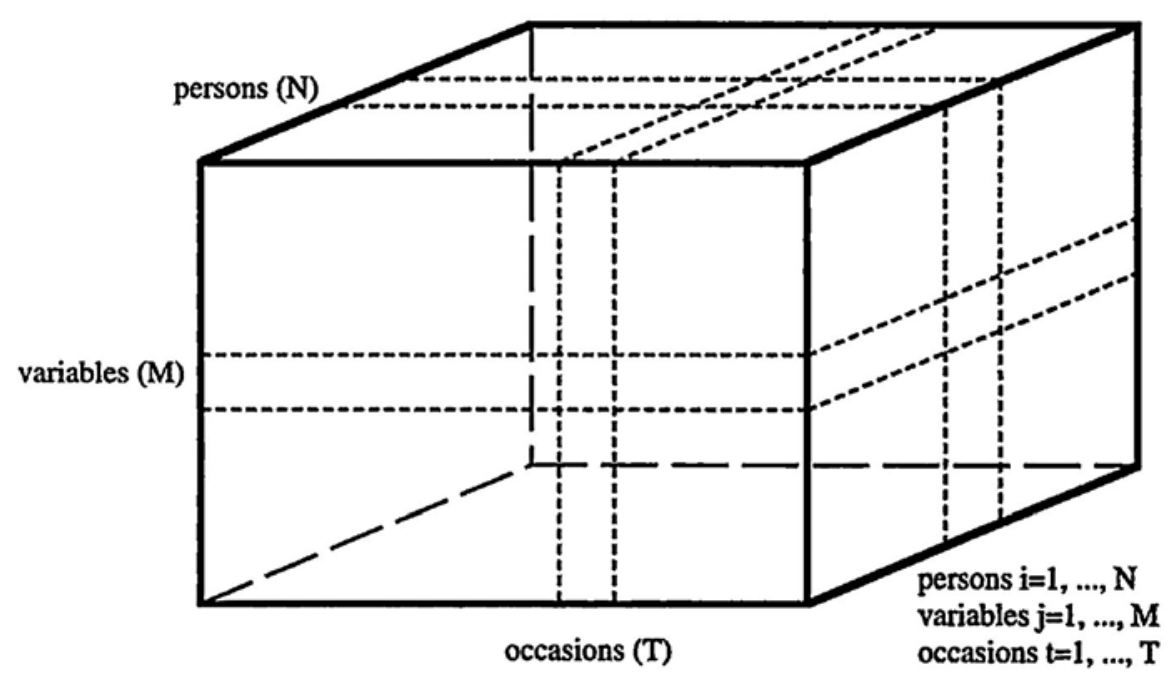

Fig. 1.

Basic Data Relation Matrix (BDRM)

Source: Catell (1988)

\section{Methodology}

The idea behind the development of this methodology was to inquire into the subjectivity of human mind. The examples of such subjectivity are limitless and include aesthetic judgment, appreciation of art, preferences for music, experiences of family after tragic events, and attitudes towards political groups. These were difficult, if not impossible, areas that could not be measured and reported scientifically by the conventional quantitative methods available at 30's. Q-methodology emerged as a direct result of that deficiency. In the 1970s and 1980s, advanced computer programs were developed to perform statistical analysis of data derived by the Q-methods. Authors have built up such model that deals with question of environmental awareness and individual attitude. Nowadays, Q-sorting has several benefits (Thomas and Watson, 2002):
- Q-sort offers a means for an in-depth study of small sample populations;

- It can help with exploratory research;

- A well-developed theoretical literature guides and supports its usage;

- It captures subjectivity in operation through a person's self-reference;

- Participants need not be randomly selected;

- It may be administered over Internet;

- Its analysis techniques help protect respondent self-reference from researcher influence.

Q-methodology "combines the strengths of both qualitative and quantitative research traditions" (Dennis and Goldberg, 1996) and in other respects provides a bridge between the two (Sell and Brown, 1984). Q-methodology is a method that provides researchers with a systematic and rigorously quantitative means for examining human subjectivity. 
Subjectivity, for this purpose, is defined simply as a person's point of view on any matter of social and/or personal importance. In this case authors have analysed the person point of view to the question of mobility, environmental protection, environmental awareness. The corollary to this conception of subjectivity, making it amenable for analysis, is that subjective points of view are communicable and are always advanced from a position of self-reference. Subjective communication thus lends itself to objective analysis in the Q-method. As such, subjectivity is always anchored in self-reference, that is the person's internal frame of reference, and, Q-studies from conception to completion adhere to the methodological axiom that subjectivity is always self-referent (McKeown and Thomas, 1988). Statistical analysis typically involves the sequential application of three sets of statistical procedures to the Q-sort data - correlation, factor analysis and the computation of factor scores (McKeown and Thomas, 1988). In light of its sophistication and broader methodological centrality, factor analysis and its applications are matters that warrant particular attention. It was first developed in psychology by Spearman (1904) and Thurstone (1931). It has been used in disciplines as diverse as chemistry, sociology, economics, and of course psychology. It is a statistical method of data reduction used to identify a small number of latent constructs (factors) that explain underlying, unobservable relationships among a large number of interrelated variables (Fig. 2). The main applications of factor analytic techniques are: (1) to reduce the number of variables and (2) to detect structure in the relationships between variables, that is to classify variables. Therefore, factor analysis is applied as a data reduction or structure detection method. Firstly, Q-methodology inverts the direction of factor extraction and correlates the persons over a set of variables instead of the variables over a set of persons. Secondly, - and this distinction is much more important than the mere difference in statistical procedure - Q-methodology follows a completely different approach to scientific reasoning. This becomes especially clear when looking at the way the isolated factors - which in the case of Q-methodology unite and represent persons, or, more precisely, their Q-Sorts - are rotated. 'Normal' factor analysis uses Varimax rotation almost exclusively because it is regarded as the

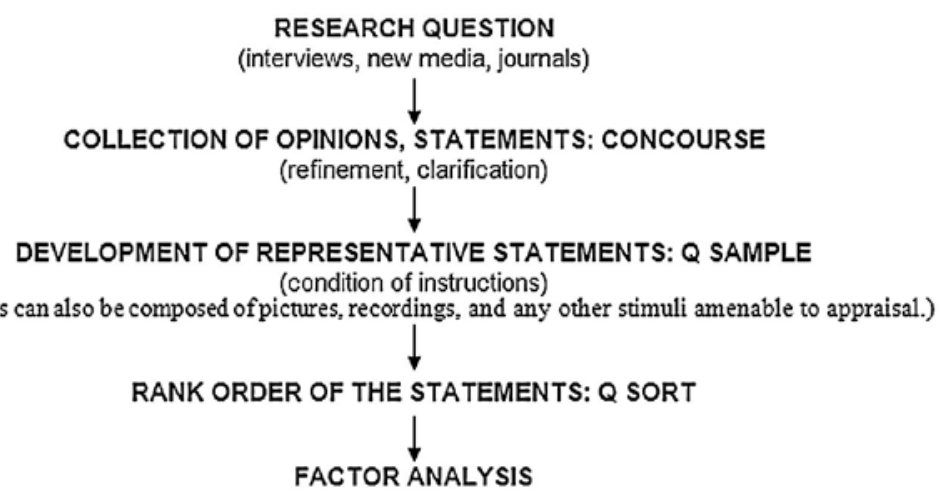

Fig. 2.

Process Overview

Source: Own Compilation 
most 'objective' procedure that provides the best results from the mathematical standpoint.

The non-automatic rotation 'by hand', which is preferred in Q-methodology, provides an infinite number of possible results that from a mathematical point of view are equal in quality. It can also be useful to include factors with eigenvalues less than 1 into the analysis, e.g. because it represents the view of a highly influential person. At this point the importance of the interviews accompanying the actual sorting becomes clear since they have to provide the necessary information to support such interpretations. As the result of the statistical analysis a number of - typically two to four factors are isolated that represent ideal types of Q-Sorts. The individual persons agree or disagree to a varying degree with each view, i.e. they correlate positively or negatively with this factor. While conventional factor analysis is used in scale development and tries to group items or variables, Q-method tries to group subjects. Therefore, people of the same group or having the same factor will have a similar pattern of chosen statements. Q-method is participantled and seeks to understand the subjective expressions and viewpoints of participants (Watts and Stenner, 2005). Q-method looks for correlations between subjects across a sample of population characteristics. Q-factor analysis reduces the many individual viewpoints of the subjects to a few "factors," which represent shared ways of thinking. It is sometimes said that $\mathrm{Q}$-factor analysis is $\mathrm{R}$ factor analysis with the data table transposed (Fig. 3).

\section{Results}

The population, in the conventional research methodological term, refers to the group of people in which the results of the study can be applied. The sample refers to those people on which the study is actually been conducted. Classical test theory assumes that each person has a "true score" ( $\mathrm{T}$ ) that would be obtained if there were no errors in measurement. A person's true score is defined as the expected

\section{primary matrix}

\section{transposed matrix}

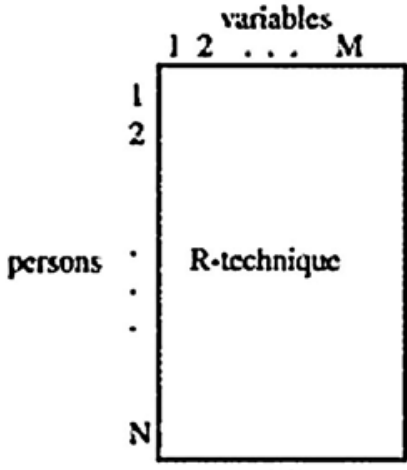

(a)

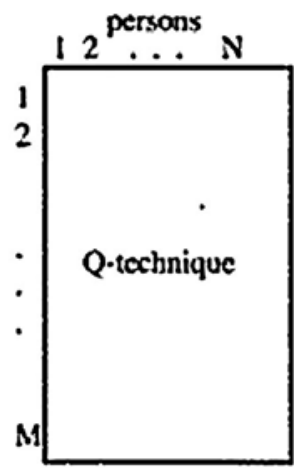

(b)

Fig. 3.

Visualisation of Transposing

Source: Cattell (1988) 
number-correct score over an infinite number of independent administrations of the test. Unfortunately, test or questionnaires never observe a person's true score, only an observed score, $X$. It is assumed that observed score $=$ true score plus some error (Eq. (1)):

$\mathrm{X}=\mathrm{T}+\mathrm{E}$

where:

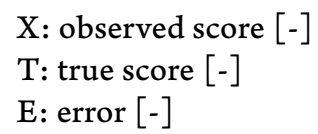

In Q-methodology, the population and the sample is not as rigidly defined as in quantitative research. The sample needs not to be randomly drawn from the population. Often times, the persons are chosen for the research because they have special relevance to the topic or hold strong views about the topics of interest. Also the sample size is relatively small and it is not unusual to have one case study in detail. In fact, the subjective distortion (the "error") can be study with Q-methodology. The first reason to adopt the Q-methodology in transportation and in the topic of environmental awareness is that it allows the participants to express their subjectivity without confining them to the researcher's categories. A Q-sort gives the sorter room to construct a picture of his or her own viewpoint and to interpret each statement in his or her own way. Of course, Q's merits on this count should not be exaggerated, as the researcher's a priori assumptions still enter into the construction of the set of statements, the selection of participants, and factor selection and rotation (Robbins and Krueger, 2000). Q-method is better able to encompass the full range of ideas that participants may have because the selection of statements is approached as sampling from a universe of possible statements on the topic - as opposed to R-method, which typically approaches the selection of statements as designing measurements of specific hypothesized characteristics (Thomas and Baas, 1992). Q-methodology is usually carried out in six stages (Barry and Proops, 2000):

1. Researchers identify a particular discourse, which is the subject of exploration, and the relevant population. Research hypothesis as it applies to quantitative research is not necessary in Q-methodology. A hypothesis reflects the viewpoint of the researcher and what he/she expects to prove or disprove by the particular research. As Q-methodology is based on an individual respondent's viewpoint and not the researchers viewpoint, each of the respondent is taken valid and as a valuable source of information research. In this paper, authors had the hypothesis that Hungarian people have low attitude towards environmental awareness in road transportation in daily life.

2. The researcher conducts structured interviews or any sources with a sample of the population. A selection of statements comes from these interviews. This set of statements is usually enlarged with additional statements originating from other sources, such as newspaper or expert literature, with the goal of gathering a collection of statements that represent a relevant communication concourse that express a range of perspectives that exist for a particular area of interest. At this stage, the researchers typically work with a set of 100-200 statements. In this research authors had question over mobility pattern, car ownership, car usage (pooling and sharing systems), transport related environmental pollution. 
3. The investigator then constructs a Q-sample. This refers to a selection of statements that will be shown to respondents, and form the basis for sorting and selection by respondents. The structure of the Q-sample reflects a given research question. A typical Q-statement set usually includes 30-60 items (stimuli).

4. Selected individuals ( $P$ sample) are asked to evaluate and order statements on a pre-prepared scale, which is pyramid shaped, with placement or scores for each statement from the Q-sample ranging from "Agree with most strongly" to "Disagree with most strongly". Q-studies commonly use 9 or 13-point scales (Fig. 4). Usually a smaller number of respondents is adequate; more important than the size of the sample is the structure.

5. The researcher statistically analyzes the data, based on Q-sorting by respondents, in order to reveal patterns across the participants. Q-methodology is based on person-by-person correlation and factor analysis process. The aim of the analysis is to identify a few "typical" Q-sorts that point out common attributes of several individual Q-sorts.
6. These typical Q-sorts are interpreted to uncover the content of shared views (i.e., discourses) with regard to the theoretical framework of the given study. Since the typical Q-sort comprises several actors' views, identified discourses are not representations of any particular individuals. They rather stand for the "bestestimate", "essential" or "ideal type" account of a view that is collectively shared within each group of actors.

\section{Analysis - Limitations of Q-Methodology}

Q-methodology is criticized for a number of reasons: generalizability to a population of people and explanation using outside variables. Generalizability to a population of people refers to the ability to say how many people in a larger population some result applies to how prevalent a given perspective is in a larger group. Generalisation refers to applicability of research findings beyond the study participants. The generalization of research data derived from Q-methodology is somewhat limited and actually not intended as well. Most of Q-methodology is exploratory in nature and tends not to be based on random sample design.

\begin{tabular}{|c|c|c|c|c|c|c|c|c|}
\hline \multicolumn{2}{|c|}{ Strongly Disagree } & \multicolumn{5}{|c|}{ Neutral } & \multicolumn{2}{|c|}{ Strongly Agree } \\
\hline-4 & -3 & -2 & -1 & 0 & +1 & +2 & +3 & +4 \\
\hline & & & & & & & & \\
\hline & & & & & & & & \\
\hline \multirow[t]{4}{*}{ (2) } & & & & & & & & (2) \\
\hline & (3) & & & & & & (3) & \\
\hline & & (4) & & & & (4) & & \\
\hline & & & (5) & & (5) & & & \\
\hline & & & & & & & & \\
\hline
\end{tabular}

Fig. 4.

Example of 13 Point Scale

Source: Own Edition from the Research 
The aim is to uncover valid and authentic opinions, in-depth analysis, and subsequent categorizations. Once certain clusters of opinions are identified, their prevalence and distribution can be determined in a population by conducting large surveys. Explanation using outside variables refers to the ability to show how a perspective is related to things outside the universe of topical statements from which the Q-statements were drawn. When repeated on the same persons Q-methodology does not necessarily yield the same results which has led to questions regarding reliability. However, social psychology sees no problem with this as there is no expectation that an individual will express the same views on two separate occasions (Stainton Rogers, 1991). It should be noted that there is some disagreement in the literature here since Brown (1980) maintains that Q-sort can be replicated with $85 \%$ consistency up to a year later. Constraint is put on the participant in terms of the items provided. Limitations are automatically placed on the participant's responses due to the predetermined statements and therefore it is argued that there are only limited accounts which can be expressed. In order to more accurately represent the views of the subjects and not rely solely on the decision making of the researcher in choosing the final selection of statements, interviews or focus group discussions about the subject matter could be conducted and the statements derived from these for use in the Q-sort. There is risk of bias at the interpretation stage as this task lies with the researcher. To take the analysis beyond the most basic descriptive and counting exercise requires the researcher's analytical skills in moving towards hypotheses or propositions about the data (Pope et al., 2000). Like other 'scales' Q-methodology relies for its effectiveness on the cooperation and frankness of the respondent. This may have its disadvantages. For one reason or another the respondent may try to fake responses or 'give a great many uncertain responses' (Oppenheim, 1992). Although, unlike with Likert-type scales

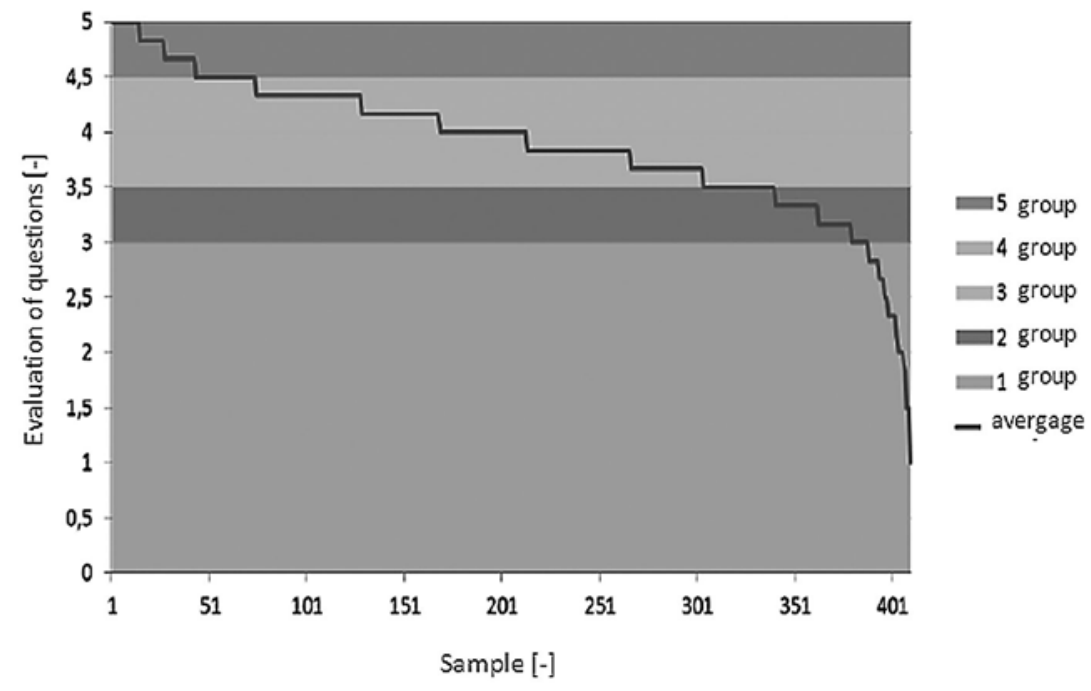

Fig. 5.

Preliminary Results of Research

Source: Own Edition from the Research 
where the number of uncertain responses is limited by the forced distribution of the statements, in the Q-sort there is still the risk that the respondent will use the instrument to give an account that they think is acceptable to the researcher rather than how they truly feel about an issue.

\section{Conclusion}

In the preliminary survey that could be a basis of further research the sample was asked on environmental awareness of transportation (Fig. 5). The people had to evaluate 6 answeres in terms of their awareness to environment. The average of points related to answeres were calculated. Based on the point, 5 groups were separated with non equidistant scales in order to get the equal sized groups.

The following chart shows that $5 \%$ of the surveyed men and $9 \%$ of women are in the first team whom concerned themselves as environemntal aware. The second group consist of respondents of $22 \%$ male and $14 \%$ women. The third group of respondents are $34 \%$ of men and $32 \%$ of women. The surveyed fourth group of $27 \%$ men and $36 \%$ women. While the fifth group has $8 \%$ men and $14 \%$ women. So with the above mentioned method further analysis is required for determining socio and econic factors that influence environmental awareness in transportation but preliminary results shows significant difference by gender. That can be a message for marketing specialist dealing with road transport related environmental awareness.

\section{Acknowledgement}

This work is connected to the scientific program of the "Development of quality-oriented and harmonized $\mathrm{R}+\mathrm{D}+\mathrm{I}$ strategy and functional model at BME" project. This project is supported by the Szechenyi Development
Plan (Project ID: TÁMOP-4.2.1/B-09/1/ KMR-2010-0002). Special thanks to Adam Török for his valueable contribution.

\section{Reference}

Barry,J.; Proops, J. 1999. Seeking sustainability discourses with Qmethodology, Ecological Economics. DOI: http://dx.doi. org/10.1016/S0921-8009(98)00053-6, 28(3): 337-345.

Barry, J.; Proops, J. 2000. Citizenship, sustainability and environmental research: $Q$ methodology and local exchange trading systems. Northampton: Edward Elgar Publishing.

Brown, S.R. 1980. Political subjectivity. New Haven, CT: Yale University Press.

Cattell, R.B. 1988. The data box: Its ordering of total resources in terms of possible relational systems. In J.R. Nesselroade \& R.B. Cattell (Eds.), Handbook of multivariate experimental psychology $\left(2^{\text {nd }}\right.$ ed.). New York: Plenum. 996 p.

Dennis, K.E.; Goldberg, A.P. 1996. Weight control selfefficacy types and transitions affect weight-loss outcomes in obese women, Addictive Behaviours. DOI: http://dx.doi. org/10.1016/0306-4603(95)00042-9, 21(1): 103-116.

McKeown, B.F.; Thomas, D.B. 1988. Q Methodology. Newbury Park, CA: Sage. 356 p.

Oppenheim, A.N. 1992. Questionnaire Design, Interviewing and Attitude Measurement. Continuum, London. 312.p.

Pope, C.; Ziebland, S.; Mays, N. 2000. Qualitative research in healthcare: analyzing qualitative data, British Medical Journal, 320(7227): 114-116.

Robbins, P.; Krueger, R. 2000. Beyond bias? The promise and limits of Q-method in human geography, The Professional Geographer. DOI: http://dx.doi.org/10.1111/00330124.00252, 52(4): 636-648.

Sell, D.K.; Brown, S.R. 1984. Q methodology as a bridge between qualitative and quantitative research: Application to the analysis of 
attitude change in foreign study program participants, Qualitative research in education. 79-87.

Spearman, C. 1904. The proof and measurement of association between two things, The American Journal of Psychology, 15(1): 72-101.

Stainton Rogers, W. 1991. Explaining health and illness: An exploration of diversity. London: Harvester Wheatsheaf. 249-267.

Thomas, D.B.; Baas, L.R. 1992. The issue of generelization in Q methodology: „reliable schematics” revisited, Operant Subjectivity, 16(1-2): 18-36.

Thomas, D.M.; Watson, R.T.2002. Q-sorting and MIS research: A primer, Communications of the Association for Information Systems, 8(2002): 141-156.

Thurstone, L.L. 1931. Rank order as a psychological method, Journal of Experimental Psychology, 14(1931): 187-201.

Watts, S.; Stenner, P. 2005. Doing Q methodology: Theory, method and interpretation, Qualitative Research in Psychology. DOI: http://dx.doi.org/10.1191/1478088705qp022oa, 2(1): 67-91.

\section{MERENJE EKOLOŠKE SVESTI U SAOBRAĆAJU ZASNOVANO NA Q-METODI}

\section{Emma Logo}

Sažetak: Sve ljudske aktivnosti, uključujući saobraćaj, utiču i stvaraju pritisak na životnu sredinu. Većina stanovništva bi kroz intervju ili razgovor potvrdila da je svesna važnosti zaštite životne sredine u saobraćaju iako bi njihovo ponašanje to osporilo. Ekološku svest je teško izmeriti „tradicionalnim“ putem pošto se realno ponašanje i ljudska subjektivnost ne mogu meriti na ovaj način. Osnovna ideja za razvijanje Q-metodologije bila je da se ispita subjektivnost ljudskog uma. $U$ ovom radu je teorijski ispitana mogućnost merenja ekološke svesti u drumskom saobraćaju pomoću navedene metodologije.

Ključne reči: Q-metoda, donošenje odluka, ekološka svest. 